\title{
Hyperbaric Oxygen in the Treatment of Radiation Proctitis and Cerebral Necrosis
}

\author{
*Bora Uysal, Hakan Gamsız, Ferhat Dincoglan, Omer Sager, Selcuk Demıral and Murat Beyzadeoglu \\ Department of Radiation Oncology, Gulhane Education and Research Hospital, Turkey
}

Submission: October 24, 2017; Published: November 02, 2017

${ }^{*}$ Correspondence Address: Bora Uysal, Gulhane Education and Research Hospital, Department of Radiation Oncology, Etlik Kecioren 06018 Ankara, Turkey, Tel: +90 31230446 89; Fax: +90 31230446 89; Email: drborauysal@windowslive.com

Abstract

Background: Hyperbaric oxygen treatment is a challenging topic for radiation side effects.

Objective: The main goal is to evaulate the results of hyperbaric oxygen to treat proctitis and cerebral radionecrosis associated with radiotherapy

Materials and Methods: 25 patients diagnosed with radiation proctitis and cerebral radionecrosis were treated with hyperbaric oxygen between 2008 January and 2017 February. 15 patients have radiation proctitis and 10 have cerebral radionecrosis. The symptoms of patients with radiation proctitis were stool frequency, hematochesia and pain. The presentation of others with cerebral radiation necrosis were headache, vertigo and dizziness. Hyperbaric oxygen of 2.4 Atmosphere Absolute was delivered for 25 patients.

Results: Stool frequency and pelvic pain in patients with proctitis was decreased after hyperbaric oxygen therapy. Symptoms of headache, vertigo and dizziness were better after hyperbaric oxygen. Also perinecrosal edema was limited and decreased wth hyperbaric oxygen therapy.

Conclusion: Hyperbaric oxygen is an effective and useful therapy for radiation necrosis and proctitis.

Keywords : Hyperbaric oxygen; Radiation proctitis; Radiation necrosis

\section{Introduction}

Hyperbaric oxygen $\left(\mathrm{HBO}_{2}\right)$ therapy has been deliveredfor wide range of diseases in the literature. Firstly in 1950's, cervical cancer and head and neck tumors were the first usage of $\mathrm{HBO}_{2}$ in addition to radiotherapy (RT). Tumor hypoxia is a major problem for radiotherapy management. It aggrevates radioresistance. Oxyic tumor cells are more radiosensitive compared to hypoxic ones. $\mathrm{HBO}_{2}$ is eminently known agent that increasing tumor oxygenation and it improves radiation results in many tumors. Brain necrosis, proctitis, layngeal radionecrosis, optic neuropathy, soft tissue and bone injuries are the challenging issuesof $\mathrm{HBO}_{2}$ management in the cancer treatment era. Also $\mathrm{HBO}_{2}$ was concomitantly used with photodynamic therapy and there was better tumor response at the end of this combination. Claustrophobia, cardiac and lung problems, pancitopenia etc. are the possible contrandications for $\mathrm{HBO}_{2}$ management [1].

\section{Material and Methods}

This original retrospective article enrolls twenty five patients of radiation necrosis and proctitis treated with $\mathrm{HBO}_{2}$ between January 2008 and February 2017. Fifteen of all had a radition proctitis and ten remaining patients had a cerebral necrosis. The patients with proctitis had stool caliber changes, diarrhea, stool frequency, hematochesia and pain. All fifteen patients had grade 2 proctitis. Vertigo, dizziness, headache were the major symptoms of the group of radiation necrosis. Ten patients had grade 1 necrosis. Fifteen patients were diagnosed with rectum adenocarcinoma and they were treated with pelvik IGRT. 45 Gy was given for fourteen patients in 1.8 Gy per fraction and 50.4 Gy was delivered just for onepatient in same daily fraction dose. Patients were managed with surgery six weeks after chemoradiotherapy. Adjuvant chemotherapy was delivered after surgery.

One patient with cerebral radionecrosis was treated with stereotactic surgery in the dose of 18 Gy. This patient had a radiological diagnosis of arteriovenous malformation. Other last ninepatient with radionecrosis had a grade 2 astrocytoma and treated with 54 Gy per 200 cGy fraction after surgery. Surgery was total excision.2.4 Atmosphere absolute (ATA) was given with multiplace hyperbaric chamber in 120 minutes for 25 patients. Patients were followed up with magnetic resonance spectroscopy (MR spectroscopy) or pelvic MR.

\section{Results}

24 patients (96\%) of all were man and $1(4 \%)$ of them was female (Table 1). Mean age was 30.6 (22-54). Stool frequency and pelvic pain was decreased and normalized after $\mathrm{HBO}_{2}$ in 


\section{Cancer Therapy \& Oncology International Journal}

the patients with radiation proctitis. Symptoms of headache, vertigo and dizziness were got better in 10 patientsof cerebral necrosis. Perinecrosal edema was decreased and limited after $\mathrm{HBO}_{2}$. Patients were followed up for median 12 months (6-22). Preraditoherapy verbal numeric scale scores were median 6 (4-10) and postradiotherapy scores were median $3(0-5)$ and it Table 1: Patient characteristics. was statistically significant $(\mathrm{p}<0.05)$. Median RT dose was 47.6 (18-54). 40\% of all patients had grade 1 cerebral radionecrosis and $60 \%$ of all had grade 2 radiation proctitis. $11.1 \%$ of cerebral radionecrosis group had an arteriovenous malformation and $88.9 \%$ of remaining had a grade 2 astrocytoma (Table 2).

\begin{tabular}{|c|c|c|c|c|c|}
\hline & Gender & Primary & RT dose & HBO dose & Purpose of HBO \\
\hline $\mathrm{P} 1$ & Male & Grade 2 Astrocytoma & 54 Gy/2 Gy & 2.4 ATA & Radiation necrosis \\
\hline $\mathrm{P} 2$ & Female & Rectum cancer & 45 Gy/1.8 Gy & 2.4 ATA & Radiation proctitis \\
\hline P3 & Male & $\begin{array}{l}\text { Arteriovenous } \\
\text { malformation }\end{array}$ & $18 \mathrm{~Gy} /$ single dose SRS & 2.4 ATA & Radiation necrosis \\
\hline $\mathrm{P} 4$ & Male & Rectum cancer & $45 \mathrm{~Gy} / 1.8 \mathrm{~Gy}$ & 2.4 ATA & Radiation proctitis \\
\hline P5 & Male & Rectum cancer & $50.4 \mathrm{~Gy} / 1.8 \mathrm{~Gy}$ & 2.4 ATA & Radiation proctitis \\
\hline P6 & Male & Rectum cancer & 45 Gy/1.8 Gy & 2.4 ATA & Radiation proctitis \\
\hline P7 & Male & Rectum cancer & $45 \mathrm{~Gy} / 1.8 \mathrm{~Gy}$ & 2.4 ATA & Radiation proctitis \\
\hline P8 & Male & Rectum cancer & 45 Gy/1.8 Gy & 2.4 ATA & Radiation proctitis \\
\hline P9 & Male & Rectum cancer & 45 Gy/1.8 Gy & 2.4 ATA & Radiation proctitis \\
\hline P10 & Male & Grade 2 Astrocytoma & $54 \mathrm{~Gy} / 2 \mathrm{~Gy}$ & 2.4 ATA & Radiation necrosis \\
\hline P11 & Male & Grade 2 Astrocytoma & 54 Gy/2 Gy & 2.4 ATA & Radiation necrosis \\
\hline P12 & Male & Grade 2 Astrocytoma & 54 Gy /2 Gy & 2.4 ATA & Radiation necrosis \\
\hline P13 & Male & Grade 2 Astrocytoma & 54 Gy/2 Gy & 2.4 ATA & Radiation necrosis \\
\hline P14 & Male & Grade 2 Astrocytoma & 54 Gy/2 Gy & 2.4 ATA & Radiation necrosis \\
\hline P15 & Male & Grade 2 Astrocytoma & 54 Gy/2 Gy & 2.4 ATA & Radiation necrosis \\
\hline P16 & Male & Grade 2 Astrocytoma & 54 Gy /2 Gy & 2.4 ATA & Radiation necrosis \\
\hline P17 & Male & Grade 2 Astrocytoma & 54 Gy/2 Gy & 2.4 ATA & Radiation necrosis \\
\hline P18 & Male & Grade 2 Astrocytoma & 54 Gy /2 Gy & 2.4 ATA & Radiation necrosis \\
\hline P19 & Male & Rectum cancer & 45 Gy/1.8 Gy & 2.4 ATA & Radiation proctitis \\
\hline P20 & Male & Rectum cancer & 45 Gy/1.8 Gy & 2.4 ATA & Radiation proctitis \\
\hline P21 & Male & Rectum cancer & 45 Gy/1.8 Gy & 2.4 ATA & Radiation proctitis \\
\hline P22 & Male & Rectum cancer & $45 \mathrm{~Gy} / 1.8 \mathrm{~Gy}$ & 2.4 ATA & Radiation proctitis \\
\hline P23 & Male & Rectum cancer & $45 \mathrm{~Gy} / 1.8 \mathrm{~Gy}$ & 2.4 ATA & Radiation proctitis \\
\hline P24 & Male & Rectum cancer & $45 \mathrm{~Gy} / 1.8 \mathrm{~Gy}$ & 2.4 ATA & Radiation proctitis \\
\hline P25 & Male & Rectum cancer & $45 \mathrm{~Gy} / 1.8 \mathrm{~Gy}$ & 2.4 ATA & Radiation proctitis \\
\hline
\end{tabular}




\section{Cancer Therapy \& Oncology International Journal}

Table 2: $\mathrm{HBO}_{2}$ indications.

\begin{tabular}{|c|c|}
\hline & HBO $_{2}$ indications \\
\hline 1 & Decompression sickness \\
\hline 2 & Arterial insufficiencies \\
\hline 3 & Acute thermal burn injuy \\
\hline 4 & Idiophatic sudden sensorineural heairng loss \\
\hline 5 & Severe anemia \\
\hline 6 & Intracranial abscess \\
\hline 7 & Necrotizing soft tissue infections \\
\hline 8 & Osteomyelitis \\
\hline 9 & Delayed radiation injury \\
\hline 10 & Compromised grafts and fleps \\
\hline 11 & Air or gas embolism \\
\hline 12 & Carbonmonoxide poisoning \\
\hline 13 & Clostridial myositis and myonecrosis \\
\hline 14 &
\end{tabular}

\section{Discussion}

Radiation complications are categorized in acute, earlydelayed and late-delayed injuries. Late injury enrolls radiation necrosis and leukoencephalopathy. Cytokines, reactiveoxygen species and vascular endothelial growth factors are leakaged to the cell membrane by inflammatory activation [2]. Chemoradiotherapy combination and the increased usage of radiosurgery caused few more cases of radiation necrosis in brain tumors. It is hard to differentiate necrosis and recurrence with conventional Magnetic Resonance (MR) but MR Spectroscopy can be used for it. Bevacizumab is a novel agent to treat radiation necrosis [3].

Temporal lobe necrosis is unusual late complication of RT in nasopharyngeal carcinoma but IMRT and helical therapies decreased its incidence. Steroids, vitamins, surgery, anticolagulants, hyperbaric oxygen, bevacizumab are the major treatment methods for radiation necrosis [4]. In an article of 2012 update by Feldmeier et al. [5], one-third of patients with delayed radiation injuries get $\mathrm{HBO} 2$ in United States. Supportive prophylactic usage of $\mathrm{HBO}_{2}$ in high-risk patients was also discussed in this article. Gynecologic malignancies are one of the potential indications for the RT treatment. Late radiation effects and $\mathrm{HBO}_{2}$ were reviewed in literature. Radiation proctitis, cystitis and necrosis should be managed with $\mathrm{HBO}_{2}$. The effect of $\mathrm{HBO}_{2}$ is decreased with the delaying time [6].

Retrospective series showed that not all but some patients with radiation necrosis of central nervous system were improved over their clinical or radiological findings after $\mathrm{HBO}_{2}$. This result is conflictive and inconsistent but it shows that differential diagnosis should be made accurately and treatment algorithm could be started as soon as possible [7]. Preventive usage of $\mathrm{HBO}_{2}$ in the management of radiation necrosis is discussed and it is not clear to start $\mathrm{HBO} 2$ before or after symptoms or clinical findings of necrosis [8]. In a series of 14 patients with gynecologic malignancy, it was shown that $\mathrm{HBO}_{2}$ is effective, safe and welltolerated management for soft tissue necrosis associated with radiation [9]. So important issue to be known is complications and side effects of $\mathrm{HBO}_{2}$. These are ocular barotrauma, ear barotrauma, dental complications and myocardial infarction [10].

Radiation proctitis is a different and challenging topic. Topical medications and oral steroids should be recommended but $\mathrm{HBO}_{2}$ and surgical interventions can be used after radiation proctitis. Improvements in radiation oncology techniques like IMRT and proton therapy lead to prevent rectal structures from radiation treatment. Also rectum spacers and balloons are still used by experts in some centers in the World [11]. Necrosis or proctitis after radiation possibly caused by decreased vascularity, hypoxia problems and leukocyte disfunction [12]. Treatment indications of $\mathrm{HBO}_{2}$ are radiation necrosis, osteoradionecrosis, diabetic foot ulcer, osteomyelitis, failed flap or skin graft. One single center experience showed that nearly $82 \%$ of patients had better outcomes after $\mathrm{HBO}_{2}$ [13].

In a study of 105 patients by Bui et al. [14], $\mathrm{HBO}_{2}$ response rate was lower for salivary, neurologic, laryngeal and upper gastrointestinal symptoms compared to mucous membrane or soft tissue necrosis. High-dose steroids have been still used for radiation induced brain necrosis. $\mathrm{HBO}_{2}$ treatment decreases steroid usage and clinical, sympomatic and radiological improvements were shown after $\mathrm{HBO}_{2}$ in similar case studies $[15,16]$. One of the largest patient registry in literature was the study by Niezgoda et al. [17] 2358 patients were analyzed in this article and the most common injuries were osteoradionecrosis, dermal soft tissue radionecrosis, radiation cystitis, radiation proctitis and laryngeal radionecrosis in decreasing order. Continued therapeutic use of $\mathrm{HBO}_{2}$ was supported and advised by authors in this large population study. 


\section{Cancer Therapy \& Oncology International Journal}

Radiosensitization of tumors with $\mathrm{HBO}_{2}$ before radiotherapy was discussed in literature. Mayer et al wrote short overview of different centers and interval between $\mathrm{HBO} 2$ and radiotherapy was 10-20 minutes [18]. $\mathrm{HBO}_{2}$ decreases symptoms of cerebral necrosis, radiation proctitis and also improves life quality. Therapeutic role of $\mathrm{HBO}_{2}$ was shown in the literature and randomized and multicenter studies are needed for future perspective of radiation complications and side effects. The results of our single center retrospective study are consistent with recent literature.Hyperbaric oxygen is an effective and useful therapy for radiation necrosis and proctitis.

\section{Acknowledgement}

No Financial support and sponsorship.

\section{Conflict of Interest}

There is no conflict of interest.

\section{References}

1. Al-Waili NS, Butler GJ, Beale J, Hamilton RW, Lee BY, et al. (2005) Hyperbaric oxygen and malignancies: a potential role in radiotherapy, chemotherapy, tumor surgery and phototherapy. Med Sci Monit 11(9): 279-289.

2. Fink J, Bom D, Chamberlain MC (2012) Radiation necrosis: relevance with respect to treatment of primary and secondary braintumors. Curr Neurol Neurosci Rep 12(3): 276-285

3. Chao ST, Ahluwalia MS, Barnett GH, Stevens GH, Murphy ES, et al. (2013) Challenges with the diagnosis and treatment of cerebral radiation necrosis. Int J Radiat Oncol Biol Phys 87(3): 449-457.

4. Chen J, Dassarath M, Yin Z, Liu H, Yang K, et al. (2011) Radiation induced temporal lobe necrosis in patient with nasopharyngeal carcinoma: a review of new avenues in its management. Radiat Oncol 6: 128.

5. Feldmeier JJ (2012) Hyperbaric oxygen therapy and delayed radiation injuries (soft tssue and bony necrosis): 2012 update. Undersea Hyperb Med 39(6): 1121-1139.

6. Allen S, Kilian C, Phelps J, Whelan HT (2012) The use of hyperbaric oxygen for treating delayed radiation injuries in gynecologic malignancies: a review of literature and report of radiation injury incidence. Support Care Cancer 20(10): 2467-2472.

7. Valadao J, Pearl J, Verma S, Helms A, Whelan H (2014) Hyperbaric oxygen treatment for post-radiation central nervoussystem injury: a retrospective case series. Undersea Hyperb Med 41(2): 87-96.

8. Kuffler DP (2012) Hyperbaric oxyge therapy: can it prevent induced necrosis. Exp Neurol 235(2): 517-527.

9. Williams JA Jr, Clarke D, Dennis WA, Dennis EJ, Smith ST (1992) The treatment of pelvic soft tissue radiation necrosis with hyperbaric oxygen. Am J Obstet Gynecol 167(2): 412-415.

10. Tahir AR, Westhuyzen J, Dass J, Collins MK, WebbR, et al. (2015) Hyperbaric oxygen therapy for chronic radiation-induced tissue injuries: Australasia's largest study. Asia Pac J Clin Oncol 11(1): 68-77.

11. Vanneste BG, Van De Voorde L, De Ridder RJ, Van Limbergen EJ, Lambin P, et al. (2015) Chronic radiation proctitis: tricks to preventand treat. Int J Colorectal Dis 30(10): 1293-1303.

12. Mathes SJ, Alexander J (1996) Radiation Injury. Surg Oncol Clin N Am 5(4): 809-824.

13. Skeik N, Porten BR, Isaacson E, Seong J, Klosterman DL, et al. (2015) Hyperbaric oxygen treatment outcome for different indications from a single center. AnnVasc Surg 29(2): 206-214.

14. Bui QC, Lieber M, Withers HR, Corson K, Van Rijnsoever M, et al (2004) The efficacy of hyperbaric oxygen therapy in the treatment of radiation-induced late side effects. Int J Radiat Oncol Biol Phys 60(3): 871-878.

15. Cihan YB, Uzun G, Yildiz S, Donmez H (2009) Hyperbaric oxygen therapy for radiation-induced brain necrosis in a patient with primary central nervous system lymphoma. J Surg Oncol 100(8): 732-735.

16. Kohski K, Imada H, Nomoto S, Yamaguchi R, Abe H, et al. (2003) Successful treatment of radiation-induced brain necrosis by hyperbaric oxygen therapy. J Neurol Sci 209(1-2): 115-117.

17. Niezgoda JA, Serena TE, Carter MJ (2016) Outcomes of radiation injuries using hyperbaric oxygen therapy: an observational cohort study. Adv Skin Wound Care 29(1): 12-19.

18. Mayer R, Hamilto-Farrell MR, van der Kleij AJ, Schmutz J, Granström G, et al. (2005) Hyperbaric oxygen and radiotherapy. Strahlenther Onkol 181(2): 113-123.

\begin{tabular}{|l|}
\hline \multicolumn{1}{|c|}{ Your next submission with Juniper Publishers } \\
will reach you the below assets \\
- Quality Editorial service \\
- Swift Peer Review \\
- Reprints availability \\
- E-prints Service \\
- Manuscript Podcast for convenient understanding \\
- Global attainment for your research \\
- Manuscript accessibility in different formats \\
( Pdf, E-pub, Full Text, Audio) \\
- Unceasing customer service \\
Track the below URL for one-step submission \\
https://juniperpublishers.com/online-submission.php \\
\hline
\end{tabular}

